\title{
SYNTHESIS OF UNSATURATED ESTERS VIA HIGHLY EFFICIENT ESTERIFICATION CATALYZED BY POLYMER GRAFTED QUARTERNARY AMMONIUM SALTS AS TRIPHASE CATALYSTS
}

\author{
ZHENG YONG LIANG ${ }^{1 *}$, LI LI WANG ${ }^{2}$, HUI LIU ${ }^{1}$, JIN SHUO HUANG ${ }^{1}$ \\ ${ }^{I}$ School of Chemical Engeering and Energy, Zhengzhou University, Zhengzhou, China \\ ${ }^{2}$ College of Pharmacy, Henan University of Traditional Chinese Medicine, Zhengzhou, China
}

(Received: March 30, 2012 - Accepted: October 3, 2012)

\begin{abstract}
A series of unsaturated esters were prepared via condensation of sodium carboxylates and alkenyl halide under the condition of macroporous polystyrene grafted quarternary ammonium salt as recyclable phase transfer catalyst, $\mathrm{NaI}$ as co-catalyst, $\mathrm{Cu}$ powder as inhibitor and $\mathrm{H}_{2} \mathrm{O}$ as solvent. Under optimal conditions, products yields are $78.2 \sim 96.0 \%$. The catalyst can be convenient recycled and reutilized for about five times without losing its activity obviously.
\end{abstract}

Keywords: green chemistry, triphase catalysis, polymer grafted quarternary ammonium salt, unsaturated ester

\section{INTRODUCTION}

Unsaturated esters are a kind of reactive plasticizer, which are important monomers in the manufacture of resin. At present, they continue to be in great demand in fields of aerospace, electronics and telecommunication..$^{1-2}$ Therefore, the development of new synthesis technology still holds great significance.

In recent years, many efforts have been carried out on the synthesis of unsaturated ester. Among various approaches, the most preferred is condensation of alkali metal carboxylate with alkenyl halide. The original condensation were generally performed under high temperature and pressure, which was uneconomical and unsafe..$^{3-4}$ Though some literatures reported synthesis can be carried in high boiling solvents, such as xylene, chlorobenzene and DMSO, at atmospheric pressure, solvents had to be used in large quantities, which caused serious pollution. ${ }^{5-7} \mathrm{In}$ order to eliminate the factor of environment unfriendly, chemists developed a new green synthesis process using water as solvent to prepare unsaturated ester in the presence of phase transfer catalyst. ${ }^{8}$ The traditional phase transfer catalysts, such as TMAC and 18-crown-6, have good catalytic activity. However, these are difficult to separate from the reaction media for recycling because of their strong solubility. ${ }^{9-10}$ It is more attractive if such reactions can be performed using reusable catalysts. Triphase catalysts(TCs) prepared by employing soluble phase transfer catalysts grafted on polystyrene, which not only inherit their soluble analogs' activity but also are easily recycled and reused. At present, TCs have been applied very well in many unit reactions, such as hydroxylation, ${ }^{11}$ halogenating, ${ }^{12}$ oxidation ${ }^{13}$ and alkylation $^{14}$, etc. However, to the best of our knowledge, application in ester condensation has not previously been reported. As part of a continuous effort to develop green esterification technology, a series of macroporous polystyrene grafted quarternary ammonium salts had been prepared and applied as TCs in synthesis of unsaturated esters in our work.

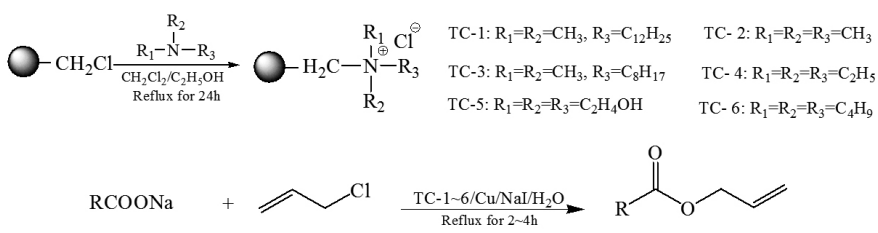

Scheme 1. Synthesis route of unsaturated esters

\section{EXPERIMENTAL}

Reagents and Apparatus

Chloromethylated polystyrene ( $\mathrm{PS}-\mathrm{CH}_{2} \mathrm{Cl}$ ) which content of chlorine is $12.8 \%$, is obtained from Hebi Resin Factory ( Henan, China). The particle size, specific surface and pore volume of PS- $\mathrm{CH}_{2} \mathrm{Cl}$ are $20 \sim 50 \mathrm{mesh}, 99.8 \mathrm{~m}^{3} \cdot \mathrm{g}^{-1}$ and $0.92 \mathrm{~cm}^{3} \cdot \mathrm{g}^{-1}$ respectively. All other chemicals (AR grade) were commercially available and used without further purification.

Infrared spectra were recorded with Bomen MB154S FT-IR spectrometer. ${ }^{1} \mathrm{H}-\mathrm{NMR}$ and ${ }^{13} \mathrm{C}-\mathrm{NMR}$ spectra was recorded on a Bruker AVII-400 $\mathrm{MHz}$ spectrometer with TMS as the internal standard in DMSO-d6. The chromaticity, acid value and iodine value determination of DAP refer to GB/T1664-95, GB/ T1668-95 and GB1676-81, respectively. All yields refer to isolated products after purification.

General procedure for preparation of PS grafted quarternary ammonium salts.

A mixture of $10 \mathrm{~g}$ PS- $\mathrm{CH}_{2} \mathrm{Cl}, 100 \mathrm{~mL}$ 1,2-dichloroethane and $40 \mathrm{~mL}$ ethyl alcohol was put into a flask equipped with stirring device, reflux condenser and thermometer. The mixture was heated up to $60^{\circ} \mathrm{C}$ for $2 \mathrm{~h}$. Quantitative tertiary amine according to $\mathrm{n}(\mathrm{Cl})$ : $\mathrm{n}$ (tertiary amine) $=1: 3$ was added. Then the mixture was kept reflux for $24 \mathrm{~h}$. After filtering, washing with ethyl alcohol and vacuum drying, the TC-1 6 were obtained.

General procedure for preparation of unsaturated esters

A mixture of $0.1 \mathrm{~mol}$ carboxylate $($ mass $=0.1 M), 2.0 \mathrm{~g} \mathrm{TC}-1 \sim 6,0.75 \mathrm{gNaI}$, $0.05 \mathrm{gCu}$ and $20 \mathrm{~mL}_{2} \mathrm{O}$ was put into a flask equipped with stirring device, reflux condenser, thermometer and dropping funnel. The mixture was heated up to $35 \sim 40 \square$ for $1 \mathrm{~h}$. Then quantitative allyl chloride according to $\mathrm{n}(\mathrm{Cl})$ : $\mathrm{n}(\mathrm{COONa})=2: 1$ was added dropwise during $2 \mathrm{~h}$. After refluxing for $2 \sim 4 \mathrm{~h}$, the excess of allyl chloride was distilled off. The reaction mixture was cooled to room temperature and filtered out quaternary ammonium salts and $\mathrm{Cu}$ powder. Then, organic layer was separated, washed with water, and dried overnight with $\mathrm{MgSO}_{4}$. The crude product was purified by vacuum distillation in presence of high boiling point solvent or by a silica-gel column chlomatography with petroleum ether and EtOAc. Products were obtained in excellent yield.

Slected Spectroscopic Data of products

Compound a: $\operatorname{IR}\left(\mathrm{KBr}, \mathrm{cm}^{-1}\right): 3083,2945,2882,1730,1649,1600,1579$, 1500, 1448, 1276. ' $\mathrm{H}-\mathrm{NMR}: \delta 4.79\left(\mathrm{~d}, J=6 \mathrm{~Hz}, 4 \mathrm{H},-\mathrm{CH}_{2} \mathrm{O}-\right), 5.27 \sim 5.48(\mathrm{~m}, 4 \mathrm{H}$, $\left.=\mathrm{CH}_{2}\right), 5.84 \sim 6.06(\mathrm{~m}, 2 \mathrm{H},=\mathrm{CH}-), 7.54(\mathrm{~d}, J=8 \mathrm{~Hz} 2 \mathrm{H}, \mathrm{ArH}), 7.79(\mathrm{~d}, J=8 \mathrm{~Hz}, 2 \mathrm{H}$, ArH). ${ }^{13}$ C-NMR: $165.8,133.5,132.5,128.2,118.3,67.2$

Compound b: IR(KBr, $\left.\mathrm{cm}^{-1}\right): 3081,3050,2951,2850,1724,1650,1603$, $1585,1450,1271,1110 .{ }^{1} \mathrm{H}-\mathrm{NMR}: \delta 4.76\left(\mathrm{~d}, J=6 \mathrm{~Hz}, 2 \mathrm{H},-\mathrm{CH}_{2}-\right), 5.25 \sim 5.62(\mathrm{~m}$, $\left.2 \mathrm{H},=\mathrm{CH}_{2}\right), 5.75 \sim 6.03(\mathrm{~m}, 1 \mathrm{H},-\mathrm{CH}=), 7.38(\mathrm{~m}, 3 \mathrm{H}, \mathrm{Ar}-\mathrm{H}), 8.03(\mathrm{~m}, 2 \mathrm{H}, \mathrm{Ar}-\mathrm{H})$. ${ }^{13}$ C-NMR: 165.9, 133.5, 132.1, 130.0, 129.8, 128.5, 67.1

Compound c: IR $\left(\mathrm{KBr}, \mathrm{cm}^{-1}\right): 3100,3050,2950,2900,1725,1650,1615$, 1581, 1460, 1380, 1270, 1100. ${ }^{~} \mathrm{H}-\mathrm{NMR}: \delta 2.35\left(\mathrm{~s}, 3 \mathrm{H},-\mathrm{CH}_{3}\right), 4.86(\mathrm{~d}, J=6 \mathrm{~Hz}$, $\left.2 \mathrm{H},-\mathrm{CH}_{2}-\right), 5.35 \sim 5.62\left(\mathrm{~m}, 2 \mathrm{H},=\mathrm{CH}_{2}\right), 7.21(\mathrm{~d}, J=8 \mathrm{~Hz}, 2 \mathrm{H}, \mathrm{Ar}-\mathrm{H}), 6.11 \sim 6.45(\mathrm{~m}$, $\left.1 \mathrm{H},-\mathrm{CH}^{2}\right), 8.08(\mathrm{~d}, J=8 \mathrm{~Hz}, 2 \mathrm{H}, \mathrm{Ar}-\mathrm{H}) .{ }^{13} \mathrm{C}-\mathrm{NMR}: 165.8,142.7,132.5,129.8$, 128.6, 127.0, 67.0, 21.4

Compound d: $\operatorname{IR}\left(\mathrm{KBr}, \mathrm{cm}^{-1}\right): 3131,3070,2950,1725,1680,1612,1530$, 1354, 1455, 1278, 1105. ' $\mathrm{H}-\mathrm{NMR}$ : $\delta$ 4.93(d, $\left.2 \mathrm{H},-\mathrm{CH}_{2}-\right), 5.42 \sim 5.73(\mathrm{~m}, 2 \mathrm{H}$, $\left.=\mathrm{CH}_{2}\right), 6.10 \sim 6.38(\mathrm{~m}, 1 \mathrm{H},-\mathrm{CH}=), 8.36(\mathrm{br}, 4 \mathrm{H}, \mathrm{Ar}-\mathrm{H}) .{ }^{1{ }^{2}} \mathrm{C}-\mathrm{NMR}: 165.9,152.3$, 136.2, 132.3, 130.6, 124.1, 67.0

Compound e: $\operatorname{IR}\left(\mathrm{KBr}, \mathrm{cm}^{-1}\right): 3075,2938,1736,1587,1363,1310,1103$, 1021. ${ }^{1} \mathrm{H}-\mathrm{NMR}: \delta \quad 4.95\left(\mathrm{~d}, J=6 \mathrm{~Hz}, 2 \mathrm{H},-\mathrm{CH}_{2}-\right), 6.10 \sim 6.23(\mathrm{~m}, 1 \mathrm{H},-\mathrm{CH}=)$, $5.33 \sim 5.57\left(\mathrm{~m}, 2 \mathrm{H},=\mathrm{CH}_{2}\right), 7.65(\mathrm{~d}, J=9 \mathrm{~Hz} 1 \mathrm{H}, \mathrm{Ar}-\mathrm{H}), 7.93(\mathrm{~d}, J=9 \mathrm{~Hz}, 1 \mathrm{H}, \mathrm{Ar}-\mathrm{H})$, 8.35 8.90(m, 2H, Py-H). ${ }^{13} \mathrm{C}-\mathrm{NMR}: 165.8,149.2,140.5,132.1,128.3,127.2$, $126.6,118.2,67.0$

Compound f: IR(KBr, $\left.\mathrm{cm}^{-1}\right): 3090,2989,2934,2861,1745,1175$. ${ }^{1} \mathrm{H}-\mathrm{NMR}$ : $\delta 2.09\left(\mathrm{~s}, 3 \mathrm{H},-\mathrm{CH}_{3}\right), 4.61\left(\mathrm{~d}, J=8 \mathrm{~Hz}, 2 \mathrm{H},-\mathrm{CH}_{2}-\right), 4.91 \sim 5.05(\mathrm{~m}, 2 \mathrm{H}$, $\left.=\mathrm{CH}_{2}\right), 5.81(\mathrm{dd}, 1 \mathrm{H},-\mathrm{CH}=) .{ }^{33} \mathrm{C}-\mathrm{NMR}: 170.5,132.2,118.2,65.5,20.8$

Compound g: $\operatorname{IR}\left(\mathrm{KBr}, \mathrm{cm}^{-1}\right): 3085,2985,2945,2885,1743,1187$. ${ }^{1} \mathrm{H}-\mathrm{NMR}: \delta 1.20\left(\mathrm{t}, J=7 \mathrm{~Hz} 3 \mathrm{H},-\mathrm{CH}_{3}\right), 2.31\left(\mathrm{q}, J=7 \mathrm{~Hz} 2 \mathrm{H},-\mathrm{CH}_{2}-\right), 4.50(\mathrm{~d}, J=6 \mathrm{~Hz}$ 
$\left.2 \mathrm{H},-\mathrm{OCH}_{2}-\right), 4.81 \sim 5.07\left(\mathrm{~m}, 2 \mathrm{H},=\mathrm{CH}_{2}\right), 5.65(\mathrm{dd}, 1 \mathrm{H},-\mathrm{CH}=) .{ }^{13} \mathrm{C}-\mathrm{NMR}: 173.8$, $132.7,118.3,65.7,27.7,9.5$

Compound h: IR(KBr, cm $\left.{ }^{-1}\right): 3092,2960,2923,2872,1759,1645,1420$, 1382, 1276, 1190, 1090, 988. 'H-NMR: $\delta 4.05\left(\mathrm{~s}, 2 \mathrm{H},-\mathrm{CH}_{2} \mathrm{Cl}\right), 4.68(\mathrm{~d}, J=8 \mathrm{~Hz}$, $\left.2 \mathrm{H},-\mathrm{OCH}_{2}-\right), 5.25 \sim 5.47(\mathrm{~m}, 1 \mathrm{H},-\mathrm{CH}=), 5.30 \sim 5.91\left(\mathrm{~m}, 2 \mathrm{H},=\mathrm{CH}_{2}\right) .{ }^{13} \mathrm{C}-\mathrm{NMR}$ : $167.3,132.5,118.5,65.3,40.8$

Compound i: $\operatorname{IR}\left(\mathrm{KBr}, \mathrm{cm}^{-1}\right): 3088,2979,1745,1345,1250,1256,1185$. ${ }^{1} \mathrm{H}-\mathrm{NMR}: \delta 2.54\left(\mathrm{t}, 4 \mathrm{H},-\mathrm{CH}_{2}-\right), 4.45\left(\mathrm{~d}, J=6 \mathrm{~Hz}, 4 \mathrm{H},-\mathrm{OCH}_{-}\right), 4.85 \sim 5.12(\mathrm{~m}, 4 \mathrm{H}$, $\left.=\mathrm{CH}_{2}\right), 5.69(\mathrm{~m}, 2 \mathrm{H},-\mathrm{CH}=) .{ }^{213} \mathrm{C}-\mathrm{NMR}: 175.0,132.1,118.7,65.6,29.9$

Compound j: $\operatorname{IR}\left(\mathrm{KBr}, \mathrm{cm}^{-1}\right): 3099,2956,1729,1512,1405,1288$, $1190,1054,811 .{ }^{1} \mathrm{H}-\mathrm{NMR}: \delta 4.72\left(\mathrm{~d}, J=6 \mathrm{~Hz} 2 \mathrm{H},-\mathrm{CH}_{2} \mathrm{O}-\right), 5.27 \sim 5.38(\mathrm{~m}, 2 \mathrm{H}$, $\left.=\mathrm{CH}_{2}\right), 6.15(\mathrm{~m}, 1 \mathrm{H},=\mathrm{CH}-), 5.95(\mathrm{q}, 1 \mathrm{H}, \mathrm{H}-\mathrm{CH}=\mathrm{CH}-\mathrm{C}=\mathrm{O}), 6.03(\mathrm{dd}, 1 \mathrm{H},=\mathrm{CH}-$ $\mathrm{C}=\mathrm{O}), 6.37(\mathrm{~d}, J=10 \mathrm{~Hz}, 2 \mathrm{H}, \mathrm{H}-\mathrm{CH}=\mathrm{CH}-\mathrm{C}=\mathrm{O}) .{ }^{13} \mathrm{C}-\mathrm{NMR}: 166.8,132.4,130.0$, $128.9,118.2,65.1$

\section{RESULTS AND DISCUSSION}

Catalytic activity and reusable property of TCs

The catalytic properties of supported phase transfer catalysts are relevant to many factors, such as the amount of grafted quaternary ammonium salts, space structure and hydrophile-lipophile balance. The catalytic effect of TC$1 \sim 6$ in preparation of diallyl phthalate (DAP) is demonstrated in Table 1.

TABLE 1. Immobilization amont of tertiary amine and catalytic capability of different TCs.

\begin{tabular}{|c|c|c|c|c|c|c|}
\hline TC & TC -1 & TC -2 & TC -3 & TC -4 & TC -5 & TC -6 \\
\hline $\begin{array}{c}\text { Amount } \\
\text { immobilized } \\
\text { /mmol. } \mathbf{g}^{-1}\end{array}$ & 2.11 & 3.90 & 2.53 & 2.83 & 1.12 & 1.43 \\
\hline Yield/\% & 91.7 & 64.2 & 81.6 & 78.7 & 81.0 & 88.5 \\
\hline
\end{tabular}

Note: $n$ (sodium phthalate $)=0.1 \mathrm{~mol}, n(3$-chloropropene $)=0.4 \mathrm{~mol}$, $m(\mathrm{TC})=2.0 \mathrm{~g}, \mathrm{~m}(\mathrm{NaI})=0.75 \mathrm{~g}, V\left(\mathrm{H}_{2} \mathrm{O}\right)=20 \mathrm{~mL}, \mathrm{~m}(\mathrm{Cu})=50 \mathrm{mg}$, reflux for $4 \mathrm{~h}$

Essentially, reaction between phthalic acid anion and allylhalide belongs to $\mathrm{S}_{\mathrm{N}} 1$ nucleophilic substitution reaction. Phthalic acid anion is a soft base according to stand of hard and soft acid and base. Based on the theory of Lewis acid-base, soft base with its hardness matching soft acid has a strong affinity. Above the six catalysts, the affinity of TC-1 with phthalic acid anion is the strongest. Besides, TC-1 belongs to high polymer cationic surfactant, which can effectively reduce the oil-water interfacial tension and promote the mass transfer. Meanwhile, compared with the traditional surfactants, TC-1 seldom causes interface emulsification, which is benefit for the subsequent separation.

It is worth noting that $\mathrm{NaI}$ exhibits excellent synergistic effect with TCs. On the one hand, TCs can provide good conditions for the substrates contacted each other; on the other hand, $\mathrm{NaI}$ reacts with allyl chloride to get allyl iodine which is highly reactive. When TC-1 was used alone, the yield of DAP is only $75.8 \%$. While TC- 1 was used in presence of NaI, the reaction proceeded smoothly in $91.7 \%$ yield at the same conditions.

The most important advantage of the triphase catalysts is easy to recover and reuse. After completion of the reaction, the catalyst was recovered by simple filtration and reused directly in subsequent reaction with approximate invariable activity. The reusage situation of TC-1 is shown in Table 2.

TABLE 2. The relationship between product yield and use times of TC-1.

\begin{tabular}{|c|c|c|c|c|c|c|}
\hline Use times & 1 & 2 & 3 & 4 & 5 & 6 \\
\hline Yield/\% & 91.7 & 89.6 & 88.2 & 89.1 & 85.7 & 83.9 \\
\hline
\end{tabular}

Note $\square n$ (sodium phthalate $)=0.1 \mathrm{~mol}, n$ (3-chloropropene $)=0.105 \mathrm{~mol}$, $\mathrm{m}(\mathrm{NaI})=0.75 \mathrm{~g}, V\left(\mathrm{H}_{2} \mathrm{O}\right)=20 \mathrm{~mL}, \mathrm{~m}(\mathrm{Cu})=50 \mathrm{mg}$, reflux for $4 \mathrm{~h}$

After using TC-1 six times, the yield of product decreased slightly, which mainly attributed to catalyst mass loss. A small amount of catalyst was grinded into powder by muddler during reaction. Unfortunately, the powdered catalyst was suspended in filtrate after filtering. If supply a small amount of fresh TC-1 for next reactions, the yield could remain unchanged.

\section{Inhibition of $\mathrm{Cu}$ powder}

Both allyl chloride and DAP have unsaturated bonds, which can generate polymerization under condition of high temperature. Therefore, inhibitor is often chosen to improve the product yield. In traditional process, phenols are frequently used as an excellent inhibitor, but they are not convenient for recovery, and possess the possibility of cancer. By contrast, $\mathrm{Cu}$ powder is an effective and easy-recycled inhibitor. Its inhibition effect is demonstrated in Table 3.

TABLE 3. The effect of $\mathrm{Cu}$ amount on reaction phenomena and yield of DAP.

\begin{tabular}{|c|c|c|c|c|}
\hline Run & $\mathbf{m}(\mathbf{C u}) / \mathbf{g}$ & phenomenon & $\begin{array}{c}\text { Yield } \\
/ \%\end{array}$ & Product color \\
\hline & & Obvious polymerization & 72.5 & Yellow \\
1 & 0 & Slight polymerization & 84.2 & Pale yellow \\
2 & 30 & No polymerization & 91.7 & Colorless \\
3 & 50 & No polymerization & 92.3 & Colorless \\
\hline
\end{tabular}

Note: $n$ (sodium phthalate $)=0.1 \mathrm{~mol}, n(3$-chloropropene $)=0.4 \mathrm{~mol}$, $\mathrm{m}(\mathrm{TC}-1)=2.0 \mathrm{~g}, \mathrm{~m}(\mathrm{NaI})=0.75 \mathrm{~g}, V\left(\mathrm{H}_{2} \mathrm{O}\right)=20 \mathrm{~mL}$, reflux for $4 \mathrm{~h}$

The product obtained from Run 5 or 7 is almost colorless liquid after vacuum distillation, whose important properties are demonstrated in Table 4.

TABLE 4. Specifications of competitive product of DAP.

\begin{tabular}{|c|c|c|c|c|c|c|}
\hline $\begin{array}{c}\text { Sepe- } \\
\text { cifica- } \\
\text { tion }\end{array}$ & $\begin{array}{c}w(\mathrm{DAP}) \\
/ \%\end{array}$ & $\begin{array}{l}\text { density } \\
\text { /g.cm }\end{array}$ & $\mathbf{n}_{\mathrm{D}}^{20}$ & $\begin{array}{c}\text { acid } \\
\text { value } \\
\text { /mg } \\
\text { KOH.g-1 }\end{array}$ & $\begin{array}{c}\text { chroma } \\
\text { (Co- } \\
\text { Pt) }\end{array}$ & $\begin{array}{c}\text { iodine } \\
\text { value } \\
/ \mathrm{gI}_{2^{-}} \\
100 \mathrm{~g}^{-1}\end{array}$ \\
\hline & 99.5 & 1.15 & 1.517 & 0.049 & $35 \sim 50$ & $\begin{array}{c}180 \sim \\
200\end{array}$ \\
\hline
\end{tabular}

\section{Reaction temperature and reaction time}

Owing to the lack of efficient catalyst system, most of the former methods to prepare DAP suffered from high temperature, high pressure or employment of high boiling solvents. In our work, the catalyst system of TC-NaI is highly active, which can remarkable lower reaction temperature and make esterification smooth progress under reflux temperature at atmospheric pressure. Along with the progress of reaction, allyl chloride was gradually being consumed and reflux temperature is risen more and more, so the reflux temperature can directly reflect the extent of reaction. Table 5 lists a corresponding relationship of reflux time, reflux temperature and product yield.

TABLE 5 Corresponding relationship of reflux time, reflux temperature and product yield.

\begin{tabular}{|c|c|c|c|c|c|c|}
\hline Reflux time/h & 1 & 2 & 2.5 & 4 & 4.5 & 5 \\
\hline Reflux temp/ ${ }^{\circ} \mathbf{C}$ & 49 & 65 & 74 & 80 & 87 & 92 \\
\hline Yield/\% & 62.5 & 79.5 & 86.3 & 91.7 & 88.2 & 80.3 \\
\hline
\end{tabular}

Note: $n$ (sodium phthalate $)=0.1 \mathrm{~mol}, n(3$-chloropropene $)=0.4 \mathrm{~mol}$, $m(\mathrm{TC}-1)=2.0 \mathrm{~g}, \mathrm{~m}(\mathrm{NaI})=0.75 \mathrm{~g}, V\left(\mathrm{H}_{2} \mathrm{O}\right)=20 \mathrm{~mL}, \mathrm{~m}(\mathrm{Cu})=50 \mathrm{mg}$

Table 5 indicates when reflux temperature reached $80^{\circ} \mathrm{C}$, esterification had closed to the end. Extending reaction time would further improve the reflux temperature, which maybe allyl chloride was hydrolyzing to allyl alcohol. When reflux temperature exceeded $85^{\circ} \mathrm{C}$, the color of reaction system converted to palm red from light yellow along with black floccule and the yield of DAP was gradually declined. It showed that effect of inhibitor decreased at high temperature, polymerization reaction happened obviously.

Applicability of the process in preparation of various unsaturated esters

Finally, this protocol was extended to the synthesis of various unsaturated esters via condensation of carboxylic acid $\mathrm{Na}$ and allyl chloride. The results under optimum conditions are summarized in Table 6. 
J. Chil. Chem. Soc., 58, No 1 (2013)

TABLE 6. Synthesis of some important unsaturated esters.

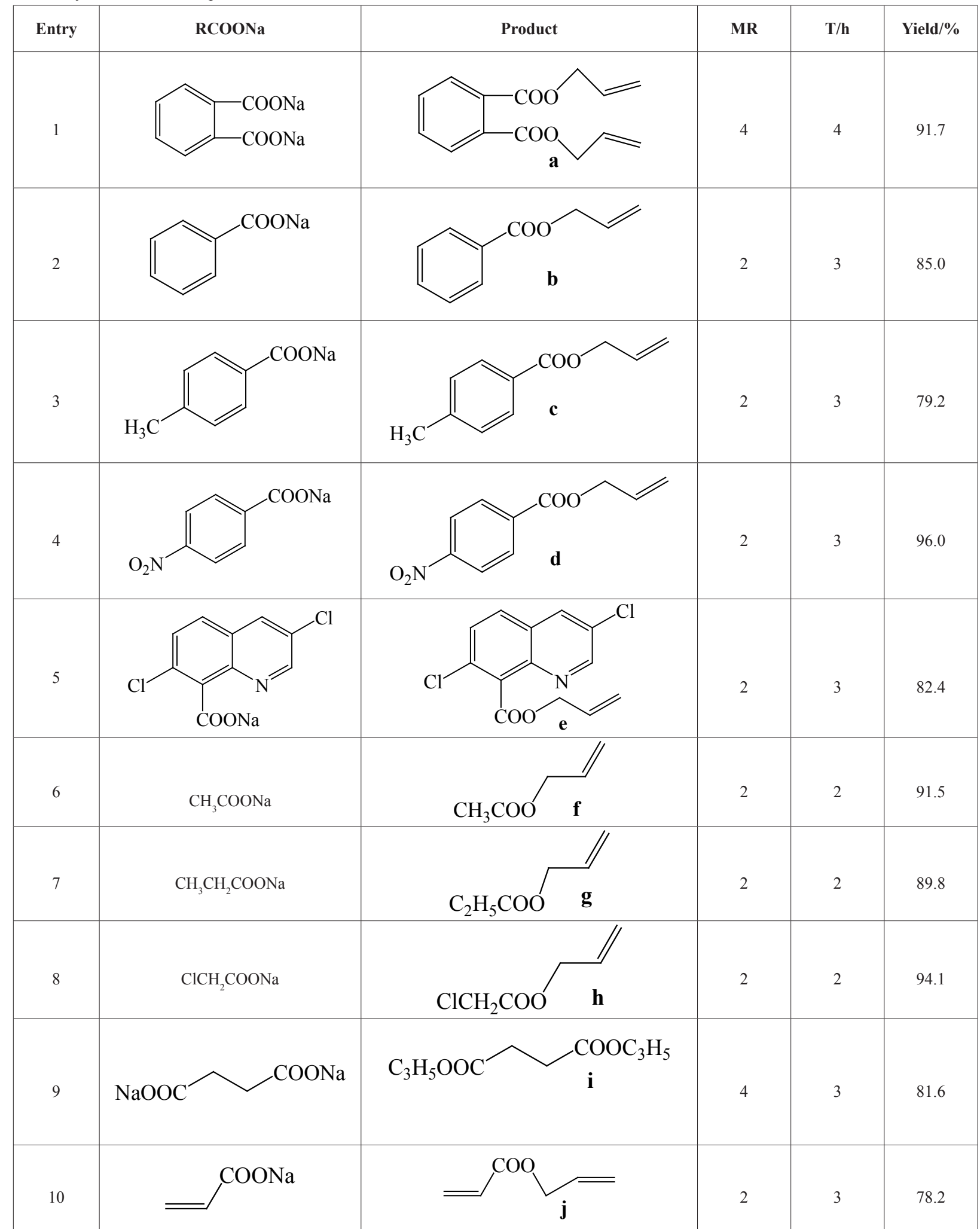

Note: $n(\mathrm{RCOONa})=0.1 \mathrm{~mol}, m(\mathrm{TC}-1)=2.0 \mathrm{~g}, \mathrm{~m}(\mathrm{NaI})=0.75 \mathrm{~g}, V\left(\mathrm{H}_{2} \mathrm{O}\right)=20 \mathrm{~mL}, \mathrm{~m}(\mathrm{Cu})=50 \mathrm{mg}$, reflux for some time; MR=Molar ratio 


\section{CONCLUSIONS}

In summary, we have developed a green, convenient and efficient protocol for the synthesis of unsaturated esters in water catalyzed by TC-NaI at atmospheric pressure. This method avoids the use of high pressure and environmentally unfavorable volatile organic solvents. The most attractive part of this work is that TCs are heterogeneous catalysts, and can be separated conveniently from the reaction media after the reaction, and can be directly reused for next time with no obvious activity declining.

\section{ACKNOWLEDGMENTS}

The authors thank the Natural Science Foundation of Henan Province, China (project no. 2011B150036) for the support of this work.

\section{REFFERENTS}

1. T. Yoshioka, T. Tsuruta, H. Iwano, T. Danhara, Radiat. Meas. 41, 513, (2006)

2. S. B. He, G. Z. Liang, J. H. Wang, H. X. Yan, Polym. Bull. 62, 237, (2009)
3. H. Stange, W. B. Tuemmler, Bisallyl esters. Patent. US 3250801, 1966, $3 \mathrm{pp}$

4. H. Sugimoto, H. Bessho, Dially phthalate. Patent. JP 19630214, 1963, $2 \mathrm{pp}$

5. O. Cerny, J. Hajek, Chem. Ind, 27, 563, (1977)

6. V. A. Ovasapyan, A. A. Pogosyan, L. L. Nikogosyan, Stroitel stvo $i$ Arkhitektura Armenii. 3, 28, (1988)

7. J. Zenko, M. Stoyanova- antoshchishina, J. Myszkowski, Proceedings of University: Chemistry and Chemical Engineering Series. 34, 9, (1991)

8. N. N. Alekseev, V. A. Lvanov, N. I Safronova, R. M. Kakovkina, Plasticheskie Massy. 6, 37, (1986)

9. J. Zienko, Premysl Chemiczny. 73, 387, (1994)

10. A. A. Akopyan, S. A. Grigor, G. O.Torosyan, A. T. Babayan, J. Appl. Chem., 62, 1904, (1989)

11. K. Rajiv, M. Priyabrata, B. Asim, Cata. Today. 49, 185 (1999)

12. F. Miyajima, T. Lijima, M. Tomoi, React. Funct. Polym. 43, 315, (2000)

13. M. A. Yamada, T. Hidetsugu, I. Masato, T. Hideyo, Tetrahedron. 60, 4087, (2004).

14. E. Murugen, P. Gopinath, J. Mol. Catal A-Chem. 309, 12, (2009). 